\title{
植物防疫論, 特に海港に於ける植物傳染病の
}

\author{
防遏方策(檢疫)に就いて。 \\ 河 村 貞・之”助 \\ Teinosuke Kawamura: Prevention of plant-epidemics, \\ with special reference to plant quarantine. \\ (Summary of the Doctor thesis presented to the \\ Department of Agriculture, Kyushu University.)
}

\section{1. 序 說}

人類に於ける惡疫の場合飞等して農林作物の病菌害 蟲も亦大牛は渡來傳播するもの，若くは躰に渡來傳播 こたものであるここが明らかで，その侵入の門后たる 海港に於てこれ在防遏するのが最上の策であるここ， 且つ又吾國輸出植物類が國家の行う检楂を經なければ 海外に進出己得ない事情こなつたここから大正 3 年農 商務省管下に植物檢查所飞こてその幾關が, 又輸出入 植物取締法さこてその法合が各々硟生した。爾來30有 餘年の間に幾多の機構上の败正を經て今日に至つた。 輪出入植物取締法に俵乃植物の檢疫行政は農產行政に 屬する一行政行第であるが，六の根柢总貫々くものが

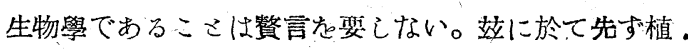

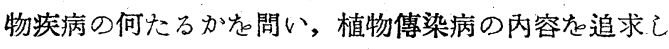
斯くこて檢疫事業に於け万生物學的本態起分析已， れ等䧱用して如何なる檢疫施”策に出ずべきやの命題 起解決す可きである。

敗戰により世界協力の一員ここて立ち上つた吾國は 今後再び諸外國この間の物資交易に必死の努力虏傾け ざる起得ず，それさ共に危險な微生物が相互に傳播さ 一るべきここが推察される。たこでこそ,檢疫に關する限 vは一腐各國の自主性危高揚己嚴重な監視の網危張り 廹らすここが即ち外國に對こて忠實なる所以こなる。

\section{2. 植物疾病論}

天然の目的即個體維持主に種族の保存に適合し且つ 正常な生活機轉を營む植物, 又は培養の目的即ち人生 への利用に適合じ生活機轉を營む處の植物龙健全な vて謂う。從つて植物疾病の觀念には主觀飞客觀こが 區別され, その生活現象怯, 健全・實用病・實害・純 正病・疾病さに分つここが出來る。
健康さ疾病さは生活現象の波動的移行性の二期で, 一の間に種々の病的狀態㤂認めねばならぬ。病的狀熊 性恢復性のものか，疾病に進行する場合の潜伏期間か であつて，その經過危相當長い期間に酉つて觀察こな い限り病健の判定は與之難い。病理學に於ては病的機 轉及び病的狀熊㤂砛究の對象飞し, 嚴密な疾病のみを 确鑚するものは特に疾病學さ呼ばれる。

純正科學の見地かららは,生活體の機能は生理的たる そ病理的たるこ在問わず含核原形質即ち細胞及びその 誘導體に關聯するものてう細胞病理學說が植物にも穻 當し，一方實用科學から疾病の重要性を觉めるにはそ の疾病に依て生ずる經濟上の損失の正しき測定が必要 である。

疫病飞は疾病の中で一定の時期に同樣の性狀を以て 同種の生物一般㤂侵すもので, 今日の解釋に從えば流 行性傳染病の謂いに他ならぬ。檢疫は主ここてこの流 行性傳染病を檢㬌取締るここた指す。

植物疾病の原因(外因內因に分ち, 外因恃寄生體己 非寄生體さに, 内因は先天的素因(種族素因)飞後天的 素因(個體素因)さに分つ。

純正の疾病さ腐敗・醴酵・頽化の諸現象さ芷區別す 可きで，例えば葚正の腐敗病（變性病）飞單なる腐敗 “現象さ九混同す可きではない。或る菌が植物の枯死己 そ器官を腐敗解體せしめなのか, 生活しつ〉ある器官 の腐敗解體の準備をなしたのか，或は兩役を寁ねたの か文何等の關與危せぬかに依つて，それ等の現象は 腐敗・疾病・附着に區分され, 菌の榮養源さ菌の榮养 方法とに依り共生菌・附着菌・腐敗菌・病菌に區別さ れる。

狟義の疾病並に賽用病を起す菌病菌之名付け, 疾 病え起す菌に非ざるも經濟上農產物に損害た及ぼす如 き菌苍害菌こ呼ぶ。 
以上の論理から, 輸出入植物取締法上の病 (疫病·疾 病）及び病菌の概念を如何に解釋すべきかさ言うに， 農產資源保護の立場から病菌及び害菌セ共に防遏の對 象さなすべきであり，その寄主若くは寄着主は必己も 生きている植物體㤂對象させず枯渴したものに就ても 取締るべきであつて，法の施行規則に言う處の「生」ば 「イキ」の意ならす「ナマ」の意に解すべきである。

施行規則の實施に當り應用すべき菌類の分類樣式を 次の如々に定めた。即ち經濟的立場からは, 病菌・不定 性病害菌・害菌・益菌・無害菌。分布過程からは, 固 有菌・自生菌・歸化菌・渡來菌＂侵入可能菌・侵入不 可能菌。生態分布からは, 草本菌・木本菌・木材菌・ 水生菌・空中菌・ 上壤菌・熱帶菌・亞熱帶菌・寒帶 菌・亞寒帶菌・特殊菌・世界兽遍菌とした。

\section{3.”植物傳染病論}

生活こている病原が植物體內に侵入己且つ篔殖した 結果, 薏起巳れる處の疾病危植物傳染病々呼ぶ。傳染 病の觀念は人醫學よv導入され，それが植物に磪證さ れたのは1900 年代で, 初期は寧万菌類學・細菌學の 一分野さこて存在した。Robert $\mathrm{KOCH}$ の病原の分離・ 培養・接種の方法は當然植物疾病の研究方法にも傳之 られ, 病原菌は細菌學・菌類學の域龙脱已て植物病理 學の中に包含論究されるに゙至つた。

凡そ傳染の意義に2つあり，1は狹義の傳染(感染) であつて，寄主體中に病原が侵入繁殖するの樣態危言

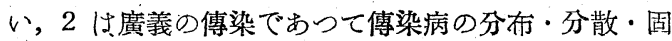
定の樣態を指すものである。

植物傳染病學の目的飞す万處は，傳染性疾病の傳播 方法㤂講究己同時に豫防の基礎㤂作るに在り, 單なる 地理統計的の基礎丈では滿足されず，實驗的研究・野外 圈場(臨床的)證明・D般統計がその補助手段さなる。

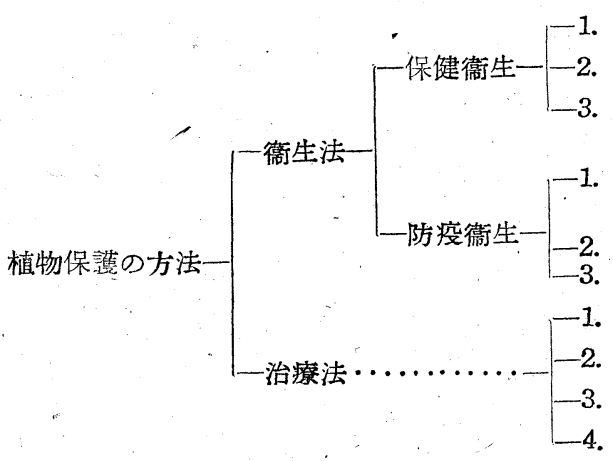

扱て本䄮の植物取締事業の內容は純然たる植物傳染 病を對象さする狟義の植物检疫已，植物の有害菌・有
植物傳染病瞢延の根源こしての分散時に於けろ病原 の諸形態は，胞子・菌核・菌絲・バイラス粒子であり 病原菌分散の諸媒體は土，空氣・水・土壤・動物・植物 農耕具・包裝物・交通機關である。而して瞢延はそれ 等病原の諸分散形態さ諸分散媒體さの組み合せに依て 起 v, 又病原の分散移動は非連續 (遠距離) 分散こ連續 (近距離)分散々の 2 型を持つ。斯くて疾病士着の原理 追究に進む。即ち種々の分散形態に於けっ病原が種々 の分散媒體に依て，連續又は非連續の形式で適當な士 地に到達するこ，病菌の發生換言すれ梌病害の發端が 起る。病原菌の發生は胞子を源さするには發牙に始ま v，胞子以外のもの虑源さする場合は胞子の成生又は 菌絲の成生等に始まる。發生には物理的・化學的及び 生物的環境抵抗が作用する。次に病原菌の土着條件飞 そて，地勢(地理的)並に氣像的・土質土性的條件飞等 主植物・病原菌の適應性等が舉げられる。

病原菌はその個體維持・種族保存の必姴上, 一地點 より他地罥に移動分散の献があり, 分散さたものは地 の利在得て土着己，䒚に植物傳染病が招來される。

畢竟するに寄主及び笴着主の分布が病原菌又は害菌 の分布を主こして支配し，氣象的因子はさ己て大なる 影響なきものの如く, 從つて北方產植物は南方產のも のに比こて檢疫に對こての重要性薄く, 熱帶・亞熱帶 に關する植物檢疫が，吾國に於ては温帶植物に關する ものに次いで重視されればならぬ。

\section{4. 植物防疫論}

傳染性立に生理的な植物疾病の防除の體系は植物保 護の名の下に一括され，“衞生さ治療さの分離は極めて 困難であるが，治療の意義を本那諸家の解したる如き 單なっ痽病器官の治澺さぜず，廣義の治療さ解するこ きは，植物保護方法は次表の如くになる。

耕種法（內的抵抗素質踽化せ己めんてするもの） 消畫法

育種法（外的障碍に打羍たんこする種族的素質危 發展せしめんさするもの) 國內檢疫 (國內に於ける病菌害蟲の傳播在防がん

國境檢疫：(國外よりの病菌害蟲の侵入)

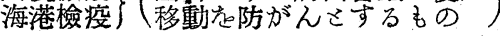

物理療法

化學藥劑療法（藥劑撒布・消毒念含む）

生物利用療法

內科・外科療法

害動植物啮象飞する植物檢查飞, 病菌害蟲の調查研 究の 3 部門から成立し, 檢疫檢查の實施方法は狹義の 
檢查さ，制限・禁止の階段に依る。尤も害菌・附着菌 の如きものに關するものも菌の傳播性質により檢疫の 下に包含己て，植物取締事業危大別こて檢疫・調查を なすは必ずこも排す可きでない。

吾國の農業形態が，廣範圍に酉つて極めて强い被害 危受け易い形態に變化己來り，且つ今後もとの方向に 變㟟するここが豫想され，又吾國が四面海以圍まれ病 菌害蟲傳播の道が限られているて考えたが反對に海洋 の開放性による危險が充分にあること，並に航空機交 通の發澾に伴つて宾海陸三次元の世界からの病菌侵入 の特異性等から植物取締事業はその必要性を論ごられ イばならぬ。

各海港に於ける現行植物取締事業の內容並にその法
的解釋，及びその生物學上・農林資源保護上の意義に 就いては纱に省略する。

病菌の侵入蔓延の防遏方式は, 行政手段(直接法) 生物學應用(間接法) こあり", 前者に於ては特に海港に 於ける輸出入植物取締の方式, 國內に於り万監視さ豫 察の制度, 病菌發生通告の義務制さ流行地の遮斷制 度, 輸出植物取締の方式が論議されねばならぬ。その 內, 海港に於ける輸出入植物取締による方式ここては 無條件許可, 禁止, 檢疫, 檢查が考察され, 更に禁止 は絕對禁止, 條件附禁止, 禁止品の特別許可に分ち行 われ, 檢疫, 檢查は原則さこて仕出地, 鐱入地の二重 檢查方式乍探用i, 原產地證明, 健康證明在仕出國に 要求すべきで，次の形式に依る危理想する。

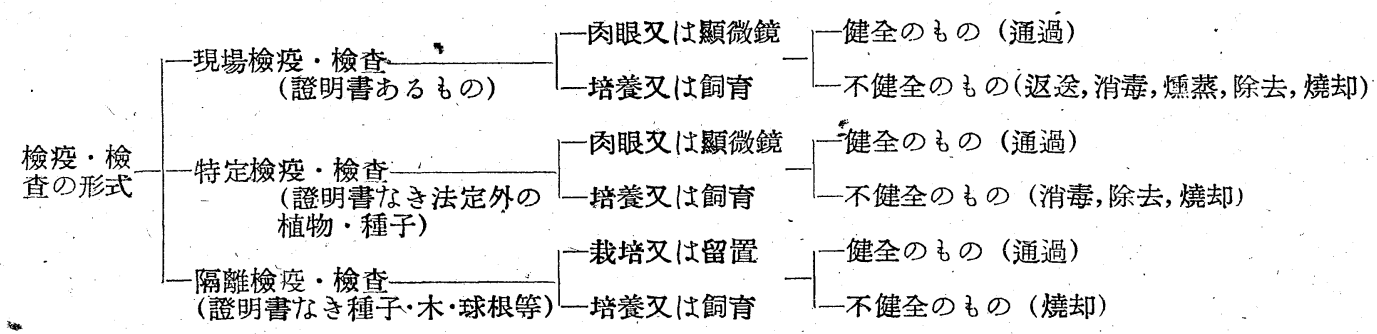

次に生物學應用とこては, 植物病害の湘量, 病菌の 藥理學己寄主植物の藥害, 病菌の生態學, 抵抗性品種 の㕕成, 調查研究の國際交換, 檢疫知識の普及徹底の 諸項目が研討され，二の學術研究飞行政手段さは嘧接 な提携在必要そする。そ゚のために先ず，外國さの交易 關係奆有する農林產物の病害䖵㤂取扱う機關飞して輸 出入植物研労所点獨立設置己, 國內のそれを取扱う農 事試驗場・林業試驗場さ聯絡する。この研究所に養成 所去併置して出先海港植物檢疫機關の聯員去養成己且 つ時々講習會龙開导, 檢度行政の生物學基礎龙磪固た ら己める。又は往年の植物檢查所を，再興して，研究部 飞檢查部をに分ち前远の研究機關走研究部にあて, 檢 查部は各海港に於りる從來の檢疫行政機關をあてるこ 己も考えられる。又海港に於りる植物取締飞府縣病害 蟲防除とが行政的に渾然一體さなる可きである。

植物保灌は農家經濟之國民食糧之の面から國家に與 えられた閣題である。鹿林作物は天侯・・病・害蟲に依 て侵害杂るが，特に著しい被害は新しく或る一團に 入つた笴生物によつて彗起され，斯ることは交通の發

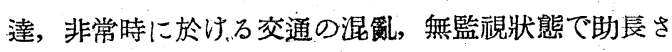
れる。そこで高度の能率をるつ檢疫機關を成立せこめ るこさが民生安定の上から緊急であつて, これ等に要 する費用・勞力・器具機械㤂最小限に止好㽍には國 家的並國際的檢疫法規を制定して各國がこれた誠實に
守るにある。聯に於て植物檢疫は植物保临に於りる進 步的な一分野なるここが認められ：これに投ゼられる 國費の意義が存在する。

日本に國外から實際に病菌害蟲の侵入するのは病菌 それ自體の分散によるょりる, 人の往來, 物資の出入 に伴うのであり，換言すれば植物檢疫は人の艾通を物 の交流に基いて發生する仕事であり，貿易形態の變化 は當然植物檢疫の態度在左右する。我國に於ては明治 開港以來 70 年間の關稅政策龙主體さ己た國際貿易の 後, 支那事變, 太本洋戰そなるに及んで南方アジ間 との軍管理の計畫交易さなり, 更に戰爭の終結によつ てアメリカ占領軍司令部の指令に基く交換貿易さなつ た。植物檢疫はえの何れの時代にも, 國內農產物の磪

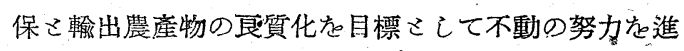
めて來た。

曾てカナダの GÜssow, H. T. 快同一問題存有己同 一地理的位置におる諸國が協定こて一團てなり，午の

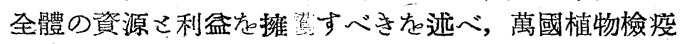
會議の結成灻說いた。一家に於ける一員の傳染病發生 時の處置は, 全世界に於ける一國の傳染病發生時處置 の縮圖、も言える。この意味に於て檢疫の internationalismは必須の思想である。この際日本は進ん でその initiative たるっべきである。

附記 本稿は九州帝國大學農學部に提出した論文の 概要である。（昭和 21 年 7 月 13 日受理當時神戸海運 局植物檢查課,現在千葉農業專門學校) 